\title{
In dubio contra fiscum - A Few Remarks on the "Barbarian" Legal Principle
}

\author{
Maciej Jońca
}

\author{
Katolicki Uniwersytet Lubelski Jana Pawta II \\ Kontaktníe-mail:macjon78@yahoo.com
}

\begin{abstract}
:
Among many fundamental rules relating to the functioning of a democratic rule of law, which do not have a Roman provenience belong famous Latin maxim in dubio contra fiscum. At the level of content, the oldest document which includes an officially expressed willingness to resolve doubts in favour of the taxpayer is the letter from King Theoderic to his treasury administrator Marcellus. The document is little-known and is usually overlooked in the world of science. The king instructs his advocatus fisci to strictly adhere to the letter of the law and win cases only on the basis of fair-play game. At the same time, when in doubt, he is obliged to acquiesce to the claims of the citizens and give up.
\end{abstract}

\section{Keywords:}

Latin legal maxims; in dubio contra fiscum; Roman fiscalism; Theodoric the Great; Ostrogothic law

DOI: $10.14712 / 2464689 X .2018 .41$

The identification with ancient Rome of everything that was built on its foundations, as well as its ruins, frequently breeds misunderstandings. This often occurs when it comes to references to legal maxims formulated in Latin. A certain automatism in the sphere of connotations leads to the conclusion that they belong to the direct legacy of the ancient Romans. Such approach has the potential to be misleading. It is indeed true that Roman law is understood as a symbol of just law and an embodiment of the highest ethical values enclosed in a collection of legal provisions. ${ }^{1}$ But fundamental rules relating to the

\footnotetext{
Cf.: KURYŁOWICZ, M. Symbol prawa ludzkiego. Szkice o prawie rzymskim w utworach Louisa Aragona i Mieczystawa Jastruna (The symbol of human law. Sketches on Roman law in the works of Louis Aragon and Mieczysław Jastrun). Lublin: Wydawnictwo UMCS, 2008, pp. 129-142; JOŃCA, M. s. v. romanesimo. In: DĘBIŃSKI, A. - JOŃCA, M. (ed.). Leksykon tradycji rzymskiego prawa prywatnego. Podstawowe pojęcia (Lexicon of the tradition of private Roman law. The basic terms). Warszawa: C. H. Beck, 2016, pp. 331-332.
} 
functioning of a democratic rule of law, such as the lex retro non agit, in dubio pro reo or audiatur et altera pars do not have a Roman provenance - neither at their semantic nor substantive level. ${ }^{2}$ The same situation can be observed with regard to the rule in dubio contra fiscum ${ }^{3}$ which is a fundamental maxim for the relation between the taxpayers and state.

\section{Advocatus fisci}

One of Benjamin Franklin's famous sayings is that there are two things certain in life: death and taxes. ${ }^{4}$ Every Roman citizen would undoubtedly agree with this statement. Citizens of ancient Rome, the Quirites, approached the matter of making wills and regulating one's financial commitments to the state with utmost seriousness. Even when Roman Italy was invaded by Hannibal's armies and the Eternal City was facing a long siege, the state demonstrated its strength by organizing conscription and collecting taxes.

The issues relating to potential disputes, which might have occurred between the treasury ${ }^{5}$ and the citizens, were taboo for a long time. Without a doubt, it must have been influenced by the fact of supplying the resources of the imperial treasury with the possessions confiscated from the persons convicted of and executed for political crimes. ${ }^{6}$ Roman jurists would not devote much attention to those issues. ${ }^{7}$

An undeniable achievement of the Romans in civilizing the relations between the state and taxpayers was the creation of the office called advocatus fisci. ${ }^{8}$ The office was created during the reign of the Emperor Hadrian with the idea of defending the interests of the state treasury. Its representatives were operative both in the city of Rome, as well as in the provinces. Inscriptions and legal sources show their alternative title-patronus fisci. ${ }^{9}$ This title is also significant in underscoring their judicial competences. ${ }^{10}$ It is not a coincidence since with the appointment of a new body of officials, the relations between the treasury and taxpayer might now be regulated through legal proceedings. ${ }^{11}$ Any such or administrative process carried out without the presence of an advocatus fisci did not have any legal effect and had to be repeated. ${ }^{12}$

2 See: JOŃCA, M. Prawo rzymskie. Marginalia (Roman law. Marginalia). Lublin: Wydawnictwo KUL, 2015, pp. 50-71.

3 A different view on this matter: SITEK, B. In dubio magis contra fiscum est responendum (D. 49.14.10). Zeszyty Prawnoustrojowe. 2015, 27, pp. 55-62.

$4 \quad$ Cited after: DUCALP, J. Anegdoty i fraszki doznanej usypiajacej własności (Anecdotes and epigrams). Wilno: Drukarnia M. Zymelowicza Typografa, 1847, p. 167.

5 For an exhaustive study on the central financial administration in ancient Rome, its structure and terminology in the sources see: KŁODZIŃSKI, K. Officium a rationibus. Toruń: Wydawnictwo Naukowe UMK, 2017, pp. 99-134.

6 MOMMSEN, T. Römisches Strafrecht. Berlin: Wissenschaftliche Buchgesellschaft, 1899, pp. 1005-1011.

7 Cf.: Dig. 43, 8, 2, 4.

8 For a complex analysis of the origin, history and the range of competences of this body, see: HIRSCHFELD, O. Untersuchungen auf dem Gebiete der roemischen Verwaltungsgeschichte. Berlin: Weidmannsche Buchhandlung, 1877, pp. 49-52. See also: LAMBRINI, P. In tema di advocatus fisci. Studia et Documenta Historiae et Iuris, 1993, 59, pp. 325-336.

9 Examples: HIRSCHFELD, c. d., p. 51.

10 An interesting coincidence is the fact that numerous jurists and statesmen started their careers with taking this office. Sources: HIRSCHFELD, c. d., p. 51 footnote 3.

11 Dig. 49, $14,7$.

12 Dig. 5, 3, 13, 9. 


\section{Roman Fiscalism - A Few Remarks}

Moving further, one should remember the hierarchical structure of Roman administration and the political climate of the period of the principate. ${ }^{13}$ Hadrian, whom historiography includes in the group of the so-called "good emperors", was as frightening to his citizens as the famously psychopathic leaders, Caligula being at the top of the list. ${ }^{14}$ If he appointed an official to represent the treasury and see to his interests, he did not do that with the view of making the life of an ordinary citizen easier.

Pliny the Younger might have been eager to praise Trajan for the fact that he had put an end to denunciatory activity, restored respect for the law and made it possible for the citizens to bring claims to the court. ${ }^{15}$ However, when he found himself in the province as the governor of Bithynia and Pontus, he quickly had to reconcile himself to the fact that in the region under his jurisdiction, there were active imperial procuratores operating in an independent way and equipped with special prerogatives. ${ }^{16}$ They would receive special instructions from the emperor (mandata) and would answer only to him. They were preoccupied mostly with the matters concerning the protection of the imperial treasury. On reading Pliny's opinions and reports in which there appears the motif of those enigmatic officials, one might venture a claim that even as a governor of the province, Pliny was a little apprehensive about them. ${ }^{17}$

In the period of the declining Roman state, fiscal burdens and bureaucracy, perpetuated by chaos and ubiquitous corruption, showed their destructive power. In numerous acts, the emperors would repeatedly threaten corrupt judges and officials, as well as governors of provinces who did not take care of the public interest. ${ }^{18}$ At the same time, they imposed upon them the obligation of the timely collection of high taxes and contributions, which was very often a burden too heavy to bear for the citizens who were often harassed by barbarian attacks, natural disasters and arbitrariness of the governing apparatus. ${ }^{19}$ In many regions of the empire, the weakness of the central power led to the emergence of mafia groups exploiting local communities. This image of misery and despair would have been accompanied by the requisitions carried out by mercenary armies, which compensated

13 Both these phenomena are described in detail and referred to the current state of research, in: KŁODZIŃSKI, c. d., pp. 33-97.

14 VEYNE, P. Imperium grecko-rzymskie. Kęty: Wydawnictwo Marek Drzewiecki, 2008, p. 29. See also: ibidem, p. 59 footnote 209: "in 1964 there was an international conference in Italy devoted to Roman emperors from Spain. When someone asked Sir Ronald Syme about his opinion of Hadrian, this distinguished man replied in French: »He was a Führer, Duce, Caudillo«."

15 Plin. paneg. 36.

16 Cf.: Plin. ep. 10.27, 10.28, 10.84.

17 Cf.: Plin. ep. 10.85. See also: DĘBIŃSKI, A. - JOŃCA, M. - LERACZYK, I. - ŁUKA, A. Pliniusz Młodszy. Korespondencja z cesarzem Trajanem. Komentarz (Pliny the Younger. Correspondence with Emperor Trajan. Commentary). Lublin: Wydawnictwo KUL, 2017, pp. 53-54.

18 See: STACHURA, M. Wrogowie rzymskiego porzqdku. Studium zjawiska agresji językowej w Kodeksie Teodozjusza, Nowelach Postteodozjańskich i Konstytucjach Sirmondianskich (Enemies of the public order. The Study of language aggression in the Theodosian Code, Post-Theodosian Novels and the Sirmondian Constitutions). Kraków: Historia Jagiellonica, 2010, pp. 193-196.

19 Among the novels of Valentinianus III, one can find two in which the emperor's wrath is directed at the officials who impose and collect taxes in an unauthorized way-Nov. Val. 7.1; 7.2. At the same time, the governors of the provinces were accused of forcing undue payments for carrying out official activities. Cf.: CTh. 7.10.1.9; 11.16.17.4; 12.1.61.3; 13.5.9.4; 15.9.2.4. 
themselves in this way for the lack of soldier's pay from the state. Therefore, the presumption that in such conditions there might have existed some prototype of the rule in dubio contra fiscum or that the authorities would take the side of the citizens by agreeing to fair court proceedings (in which both parties would be equally treated) sounds like a bitter joke.

In numerous places, the decline of imperial rule and the establishment of barbarian kingdoms in its ruins was greeted with genuine relief. Ethnically foreign tribes, which in the first half of the $5^{\text {th }}$ century spread over the large parts of the empire, would occasionally demonstrate brutality. However, the scale of financial oppression on the side of barbarian rulers was not comparable to the inhumane fiscal drainage constantly experienced by the people under Roman rule.

\section{Roman Prototype?}

In the $16^{\text {th }}$ century ancient Rome served historians, artists and scholars as a model of an ideal state. In good-faith, it was forgiven all instances of cruelty and injustice. Morally ambiguous activities were easily and skilfully justified.

In the $16^{\text {th }}$ century, the phrase in dubio contra fiscum was already well rooted in legal terminology. It appears, amongst others, in the work De Praesumptionibus, coniecturis, signis, \& indiciis of 1587 written by Giacomo Menochio. ${ }^{20}$ Francesco de Alfaro in his dissertation Tractatus de officio fiscalis deque fiscalibus privilegiis places the principle among the rules pertaining to the functioning of the treasury of the state. ${ }^{21}$ A modern, humanitarian appeal is given to it by Samuel Stryk, an eminent representative of the trend usus modernus pandectarum. ${ }^{22}$ Friedrich Pufendorf connects the discussed rule with the inheritance proceedings which entail the involvement of the state treasury. ${ }^{23}$ Everard Otto refers to the rule in the context of the privileges of the treasury, which, in his opinion, should not be subject to the broadening interpretation. ${ }^{24}$

The fragment which provided material for the creation of rule in dubio contra fiscum in a literal sense has been consistently attributed to the Roman jurist Modestinus. It was preserved due to the fact that it had been included by the compilers of Justinian in the fortyninth chapter of the Digest. It says: Non puto delinquere eum, qui in dubiis quaestionibus contra fiscum facile respondent. ${ }^{25}$

By highlighting the appropriate fragments of the text, it is easy to understand how the principle was created. It happened by cutting out and combining the two phrases in dubiis

20 MENOCHIUS, G. De Praesumptionibus, coniecturis, signis, \& indiciis. Libri III. Coloniae Agrippinae: Apud Joannem Gymnicum, 1587, p. 417.

21 DE ALFARO, F. Tractatus de officio fiscalis deque fiscalibus privilegiis. Matriti: Ex Typografia Regia, 1780, p. 62.

22 Samuelis Strykii JC. Specimen usus moderni pandectarum a libro XXIII usque ad finem. Florentiae: Apud Josephum Celli, 1841, col. 1358-1359. The author recalls the conversation of King Philip II of Spain with a learned jurist don Valasco with regard to the issues related to income from the lease of estates belonging to the Spanish crown. The king addresses his interlocutor with the following words: "doctor, always take it into consideration and pass it on to the court: in case of doubt, you should always rule against me" - ibidem, col. 1359: doctor, semper in cura habe, et renuncia senatu: in dubio semper contra me iudicandum esse. PUFFENDORF, F. Observationes iuris universi. Vol. II. Hannoverae: impensis Hoeredum Foersteri, 1748, pp. 65-66.

24 OTTO, E. Thesaurus Iuris Romani. Vol. II. Trajecti ad Rhenum: Apud Joanni Broedelet, 1733, p. 686.

25 Dig. 49, 14, 10. 
and contra fiscum. Next, the plural form in the first phrase was replaced with the singular, which seems stylistically better. Therefore, the sentence Non puto delinquere eum, qui in dubiis quaestionibus contra fiscum facile respondent gave rise to the principle in dubio contra fiscum.

However, let us move back to the original phrasing. There is little doubt that the opinion expressed by Modestinus might have had significance in the ideology of enlightened absolutism in the $16^{\text {th }}, 17^{\text {th }}$ and $18^{\text {th }}$ centuries. Later, there was an attempt to regulate social relations in the $19^{\text {th }}$-century capitalist societies on the basis of the Roman principle. ${ }^{26}$ Roman law was at that time used in all seriousness as tertium comparationis and provided a basis for choosing arguments in favour of one concept or another. However, if we look at this rule from the perspective of classical realities, it is hard to resist a conclusion that the rule is a very conservative one, very general and almost bland. Originally it was a singular, private opinion expressed by otherwise one of the respectable jurists. ${ }^{27}$ It was related to a specific case, about which, thanks to the "helpfulness" of the Justinian commission, we know absolutely nothing.

Why has this phrase received such a bitter assessment? Let us take a closer look. The expression non puto to be found there should be translated as "I do not think". It can hardly be viewed as a principled way of narration, can it? Further exegesis leads us to the conclusion that there is no certainty if it related to the reality of court proceedings. The very verb respondere, even though not deprived of connotations of court proceedings, ${ }^{28}$ in the world of Roman jurisprudence was related rather to providing legal counselling and giving expert opinions, which only later might be presented in court. ${ }^{29}$

The above circumstances were not unfamiliar to the translators of the $49^{\text {th }}$ book of the Digest, working under the leadership of Tomasz Palmirski. In the first Polish translation of the work, the sentence Non puto delinquere eum, qui in dubiis quaestionibus contra fiscum facile respondent was translated as follows: "Nie uważam, że ten, kto w odniesieniu do spornych kwestii da z łatwością odpowiedź przeciwną <interesom> skarbu państwa, popełnia przestępstwo." ("I do not think that the person who, with regard to ambiguous matters, easily gives an answer contrary to the <interests $>$ of the state treasury commits a crime."). ${ }^{30}$

It seems that Modestinus's opinion assumes the form not so much of a precursor to the modern principle, which is one of the foundations of the democratic rule of law, but rather as a way of reassuring his colleagues. In a cautious way (non puto - I do not think),

26 Some of the problems related to the above issues are pointed out in: SÓJKA-ZIELIŃSKA, K. Wielkie kodyfikacje cywilne. Historia i wspótczesność (The great civil codifications. History and modernity). Warszawa: Liber, 2009, pp. 48-50, 59-61, 77-78, 99-101, 281-286.

27 See: KUNKEL, W. Herkunft und soziale Stellung der römischen Juristen. Köln-Weimar-Wien: Böhlau, 2001, pp. 259-261.

28 Its basic meaning is "to respond". Thus, it denotes responding to the questions of the court, giving a statement of defence or responding to the claims of the other party. In legal sources, respondere does not refer to the passing of a verdict. Cf.: HEUMANN, H. G. - SECKEL, E. Handlexikon zu den Quellen des römischen Rechts, s.v. respondere. Jena: Fischer, 1907, p. 514.

29 BERGER, A. Encyclopedic Dictionary of Roman Law, s.v. responsa prudentium. Philadelphia: The American Philosophical Society, 1953, s. 681.

30 PALMIRSKI, T. (ed.). Digesta Justyniańskie. Tekst i przektad. Księgi 48-50 (Justinian Digest. Text and translation of Books 48-50), vol. VII.2. Kraków: Poligrafia Salezjańska, 2017, p. 205. 
the jurist conveys the message to them that in the case of issuing an opinion contrary to the interest of the state treasury, they should not fear being accused of a political crime.

Modestinus must have encountered ways of understanding and interpreting the laws concerning offences against the dignity of the state, as demonstrated by soldier-rulers who became the scourge of the empire after the murder of the even-tempered Alexander Severus. In the second half of the $3^{\text {rd }}$ century AD, in a similar way to the times of Nero or Domitianus, the lives of numerous people who had contact with the apparatus of the state hung by a thread for many years.

Regardless of the way Justinian compilers and their medieval and modern successors understood the phrase non puto delinquere eum, qui in dubiis quaestionibus contra fiscum facile respondent, in the $3^{\text {rd }}$ century it did not refer to taxpayers who brought legal action against the state, but to the jurists who issued an opinion that was unfavourable to the state.

\section{Emphatic "Barbarian"}

In-as-much as it is difficult to determine when exactly the principle in dubio contra fiscum was literally formulated, at the level of the subject matter, one's research must start with the official documents sent to various addressees on behalf of the Ostrogothic king Theoderic, who ruled Italy since 493 bearing the title of the King of the Goths and Romans. ${ }^{31}$

It might seem surprising that this monarch turned out to be one of the most enlightened rulers of that time. He did not oppose the Latin culture which had been rooted on the Apennine Peninsula for centuries, nor did he interfere with its progress. ${ }^{32}$ He retained the long-lasting authority of the Roman Senate. ${ }^{33}$ He supported the Church and treated his Roman subjects with kindness and understanding. He announced the famous "Edict of Theoderic," which resulted in a rapprochement between the Romans and Goths. ${ }^{34} \mathrm{He}$ preserved the court ceremonial, together with numerous offices of centuries-old history. The advocatus fisci was one of them.

Another surprising element is the discovery that the documents, whose content ties in well with the contemporary principle in dubio contra fiscum, are to be found not in the "Edict," as might have been expected, but in the collection of royal decisions gathered by Cassiodorus. ${ }^{35}$ In the most spectacular of the above documents, which will be quoted below in extenso, the King of the Goths and Romans addresses one Marcellus, a person not exactly known. In the letter, the monarch appoints him to the publicly exposed and highly influential office of the advocatus fisci.

31 See: HEATHER, P. Theoderic, King of the Goths. Early Medieval Europe, 1995, 4.2, pp. 145-173.

32 On the subject of Theoderic's politics in Italy - MOORHEAD, J. Theoderic in Italy. Oxford: Clarendon Press, 1992. On the subject of the social structure of the peoples inhabiting the Apennine Peninsula in the $6^{\text {th }}$ century AD - ARMORY, P. People and Identity in Ostrogothic Italy. 489-554. Cambridge: Cambridge University Press, 1997.

33 A detailed analysis on the subject - SCHÄRFER, CH. Der weströmische Senat als Träger antiker Kontinuität unter den Ostgotenkönigen. Hamburg: Scripta Mercaturae Verlag, 1991.

34 A detailed analysis on the subject of the content, circumstances and the social background of the "Edict of Theoderic" - MAFFERTY, S. D. W. Law and Society in the Age of Theodoric the Great. A Study of the Edictum Theodorici. Cambridge: Cambridge University Press, 2013.

35 See: KAKRIDI, CH. Cassiodors Variae. Literatur und Politik im ostgothischen Italien. Leipzig - München: K. G. Saur, 2005. 
The form of narration makes it possible to feel the rhetorical tone, which is so characteristic of royal documents. ${ }^{36}$ At the beginning, the king explains in a clear way the reasons behind his decisions of a personal nature:

The glory of the royal generosity is complete when the privileges go hand in hand with the opinions and there is no room for accident in what is weighted in good management, as where the offices correspond to the merits, nothing should be granted to unreliable persons. We do not venture opinions about the 'common people', but preferably about the proven ones. ${ }^{37}$

Next, we read about the virtues of the person appointed to the post:

You have polished your oratorical talent on the court whetstone; you have created art by taking part in trials; you have experienced the fruits which are produced by faithfulness, which wins the hearts of rulers. Our discernment, which is looking for virtues, has found them in you. You have earned our appreciation and are worthy of dealing with public matters as so far you have honestly dealt with private ones..$^{38}$

However, the key parts for the discussion on the roots of the principle in dubio contra fiscum are to be found in the last two fragments of the letter. In the appointing formula, the king nominates and, at the same time, instructs his official:

Take up therefore the duties of the administrator of the treasury, following the example of the predecessors in enjoying the benefits of the office. Thus, walk the path of justice with moderation, so that you do not harm the innocent with deception or free liars from just accusations. We believe that the real benefit is everything we gain thanks to honesty. We do not ask, therefore, how many times you win, but how you win. ${ }^{39}$

The culmination of the ruler's considerations is not only extraordinary, but astounding:

If you want to be liked by us, act in the interest of justice; do not seek victory thanks to our authority, but rather by virtue of the law, because it is better for the treasury to lose rather than for injustice to happen. When a master wins, there occurs hatred resulting from repression; whereas equality is believed in when it happens that a claimant wins.

36 See: KASJODOR SENATOR. Variae. Transl. Kołtunowska, A., Sawa, R. Kraków: Wydawnictwo WAM, 2017, pp. 30-31.

37 Cass. Var. 1.22.1: Solida laus est regiae largitatis, quotiens conveniunt indulta iudiciis, nec sibi audet casus ascribere, quod bonae dispositionis librat examen, quia ubi aptantur officia meritis, nil debetur incertis. Non enim de rudibus sententiam ferimus, sed de probatissimis iudicamus.

38 Cass. Var. 1.22.2: Polisti siquidem forensi cote multifarie praedicatus ingenium: nutristi facundiam exercitatione causarum: expertus es, quam suaves fides afferat fructus, ut ipsa etiam conciliet corda regnantum. Haec in te speculator virtutum noster sensus inspexit: his apud nos suffragiis placere meruisti, ut dignus existeres ad publicas causas, qui gessisti hactenus sub integritate privatas.

39 Cass. Var. 1.22.3: Sume igitur fisci nostri tuenda negotia, in utendis officii tui privilegiis decessorum exempla secuturus. Ita ergo per medium iustitiae tramitem moderatus incede, ut nec calumnia innocentes graves nec iustis petitionibus retentatores exoneres. Illa enim lucra vera iudicamus, quae integritate suffragante percipimus. Non ergo quotiens superes, sed quemadmodum vincas, inquirimus. 
We are discussing matters posing considerable danger as the farther an unjust benefit moves away, the more our good name increases. Hence, let the proceedings be unfavourable to the treasury from time to time, so that the benevolence of the ruler would be demonstrated. We will lose more if we gain an unjust victory. ${ }^{40}$

What does the above mean? First of all, in the state under Theoderic's rule the office of advocatus fisci was retained among the antique positions. What is more, in accordance with the ancient regulations, the citizens had the right to take legal action against the state treasury and the ruler not only accepted this but even encouraged his citizens to this way of protecting their rights.

Marcellus, whose name in the ancient sources appears only in the above letter, ${ }^{41}$ prior to being appointed to the position of the king's representative, had let himself be known as a top specialist, who had amassed huge experience throughout innumerable court proceedings. An average citizen stood no chance when confronted with such an expert. When it happened that the chances of both parties were equal, Marcellus could always resort to the authority of the ruler who stood behind him and exert an influence on the court. This is precisely what Theoderic forbade him to do. The king's advocatus fisci had to adhere strictly to the letter of the law and win cases only on the basis of fair-play values. At the same time, when in doubt, he was instructed to acquiesce to the claims of the citizens.

\section{Summary}

None of the available Roman sources includes the literally formulated principle in dubio contra fiscum. The political climate of the empire did not allow for the creation and application of the rule to such a degree, as might have been expected by contemporary societies, raised in the climate of respecting life, imbued with the ideas of the equality of all people before the law and living in democratic states. The Roman emperor and his personnel representing the interests of the state treasury could incidentally issue a decision in favour of the taxpayer or take his side in the case of a trial. However, such a turn of events would be of an incidental nature and was absolutely impossible to predict.

In the realities of the Roman imperial autocracy, especially in the period of post-classical decline in the development of Roman law, the principle in dubio contra fiscum did not even have a postulatory character. In the $5^{\text {th }}$ century $\mathrm{AD}$, the empire of the centuries-old tradition collapsed not only as a result of the pressure from the side of the so-called barbarians. In fact, the ruthlessness and brutality of the fiscal state apparatus led to the situation in which the citizens stopped identifying with their own homeland.

At the level of content, the oldest document which includes an officially expressed willingness to resolve doubts in favour of the taxpayer is the letter from King Theoderic to his

40 Cass. Var. 1.22.4: Aequitatem nobis placiturus intende: non quaeras de potestate nostra, sed potius de iure victorias, quando laudabilius a parte fisci perditur, cum iustitia non habetur. Nam si dominus vincat, oppressionis invidia est: aequitasvero creditur, si supplicem superare contingat. Non ergo parvo periculo causas dicimus, quando tunc fama nostra proficit, cum se commoditas iniusta subducit. Quapropter sit interdum mala causa fisci, ut bonus princeps esse videatur. Maiori quippe compendio perdimus, quam si nobis indebite victoria suffragetur.

41 ZIMMERMANN, O. J. The Late Latin Vocabulary of the "Variae” of Cassiodorus with Special Avertence of the Technical Terminology of Administration. Washington: Catholic University of America Press, 1944, p. 193. 
treasury administrator Marcellus. The document is little-known and is usually overlooked in the world of science. A twist of fate has caused that in the cases of conflict between the fiscal interest of the state and that of an individual the biggest humanitarianism was demonstrated by the King of the Goths and Romans, who until this day is denigrated in some studies as a "barbarian". However, if Theoderic's stance as demonstrated in this and many other issues deserves the label 'barbaric', also the principle in dubio contra fiscum should be designated by this adjective. 